\title{
CHALLENGES FACING WOMEN CAREER MOBILITY IN PUBLIC AND PRIVATE UNIVERSITIES IN KENYA.
}

\author{
Janerose Mutegi Kibaara, $\mathbf{P h D}^{1 *}$ \\ Kenya Methodist University P.O box66315-00800 Nairobi, Email: jkaithi@gmail.com
}

*Corresponding Author: -

Email: jkaithi@gmail.com

\begin{abstract}
: -
The study aimed at investigating the challenges affecting women career mobility in educational management in private and public universities in Kenya. The main objectives of the study were; to establish the challenges hindering women from progressing in their careers in public and private universities in Kenya, to examine the interventions put in place by both public and private universities in Kenya to address the challenges facing women in their career progression in private and public universities in Kenya.

The following were the main findings of the Study:

Women faced insurmountable barriers as they navigated through their career path in universities in Kenya. These challenges faced by women contributed to low number of women in the realm of university management in public and private universities in Kenya.

Some of the challenges included: Lack of mentors, family responsibilities, lack of social networks, lack of training and development opportunities, socialization of men and women and aspirations of women, and cultural values and attitudes that view women as inferior.

The study therefore concluded that there was need to change societal attitudes and cultural situation that influenced female participation in management to make them more competitive. There was need to put into practice a criteria for recruitment and promotion of university managers and implement available policies to increase women participation in university management and reduce the challenges that they encounter in their career mobility in public and private universities in Kenya.
\end{abstract}

Keywords: - Challenges, facing, women, public, universities, Kenya

\section{(c) $(\$)$}




\section{INTRODUCTION}

Women have lagged behind as far as equity in all spheres of life is concerned and their participation in education management relative to men decreases at successive higher levels.

World Bank report on gender and development (2003) noted that the number of women holding management positions was lower than that of men. In Kenya traditionally, women were viewed as inferior to men and marginalized in all sectors of development, Chacha (2004). There was need to look at the position of women in university management in public and private universities in Kenya.

The purpose of the study was to investigate the challenges affecting women career mobility in public universities in comparison to the private universities in Kenya.

Dines (1993) in her study on women in higher education management in universities in commonwealth countries said that cultural perceptions of the roles which women are expected to fill are reflected in the extent to which women participate in management. Dines further observes that majority of women in agrarian cultures were destined to hard physical labour, domination by patriarchal systems of family life and limited to mastering and nurturing arts and crafts necessary for the survival of the community and appropriate to their servant role.

Cubillo and Brown (2003) observed that management positions in this sense "belong to male members of the society and women should refrain from attempting to attain this kind of position."Otherwise, they are susceptible to various social sanctions such as reduced chance to marry (www.unesco.org, February, 2011). Brewer (2008) the chief executive of Equality and Human Rights Commission of United Kingdom noted that:

young women's aspiration is in danger of giving way to frustration. Many of them are now excelling at school and are achieving great things in higher education. They are keen to balance a family with a rewarding career, but work place forged in an era of 'stay at home mums' and bread winner dads are putting too many barriers in the way resulting in an avoidable loss of talent at the top.

The report cited a worrying trend of reversal or stalled progress on gains by women populace.

Dines (1993) observed that few institutions in society change as slowly as social relationships and few as it would appear, more slowly than the systemic discrimination of women. Where there is change it has tended to be for such pragmatic reasons as the need to tap into the extra resources that the female workforce represents for boosting a nation's economy, (Dines, 1993). Research on gender equity in commonwealth higher education by World Bank (2005) showed that in spite of advances which women had made in many areas of public life in the two decades, in the area of higher education management they are still far from participating on the same footing as men.

World Bank (2003) report on gender and development noted that gender equity is very important to any country's development and any substantial development in any nation requires the participation of both men and women. The report further observed that the number of women holding management positions was lower than that of men. Women were reported to be making slow and uneven progress in their careers.

\section{Statement of the problem}

Women have lagged behind as far as equity in all spheres of life is concerned and their participation in education management relative to men decreases at successive higher levels. In Kenya women are grossly under-represented in management positions where major decisions are made and it remains one of the countries where women have made little progress in their career mobility to management positions. This is particularly true in public and private universities in Kenya. Statistics indicate that only $18 \%$ of women are in positions of senior lecturers and above and only $0.6 \%$ are DVCs and above. Available research indicates that promotion in public and private universities is tilted in favour of men.

Kenya is a highly patriarchal society therefore the status of women remains relatively low compared to that of men. Women still remain marginalized and gender inequality prevails socially, academically, economically and professionally. Women play a key role in society therefore they need to be in the fore front when it comes to university management. For instance, the female university students look at them as role models, therefore, if they are lacking in management positions, the young girls will not aspire to occupy such positions or to pursue further education because they will have no one to inspire them.

Most of the decisions are made by those people in management positions, if women do not occupy these positions, all decisions will be made from men's point of view which may disadvantage women and work against enhancement of gender equity. With the knowledge of gender inequity in university management, the study sought to look at the interventions put in place by public universities in comparison to the private universities in Kenya to enhance women career mobility in educational management.

\section{Objectives of the study}

The main objectives of the study were to;

1. Establish the management positions occupied by men and women in public universities in comparison to private universities in Kenya.

2. Establish the challenges hindering women career mobility in public universities in comparison to private universities in Kenya. 


\section{Theoretical Framework}

Gender and feminist theories explain the development of gender and the underlying impact of the environment of nurture on the difference between males and females in the society. The research was guided by the liberal feminism theory propagated by Mill J (1998). He believed that both sexes should have equal rights under the law and that;

Until conditions of equality exist, no one can possibly assess the natural differences between women and men, distorted as they have been. What is natural to the two sexes can only be found out by allowing both to develop and use their faculties freely.

The liberal feminist critique of organization power has focused on how to increase women's power and influence by working within the current polices and structures, and hoping to promote change from within. The focus of the discussion in this study on challenges affecting women career mobility in public and public universities has an underlying assumption that reforming and changing the practices within the existing structures and policies of the universities will eventually result in a greater equity in gender representation at the top of university management in public and private universities in Kenya.

\section{Research Design}

The study applied a descriptive survey research design. Descriptive survey design was appropriate as it involved collecting data to test questions concerning the current status of subjects of the study which ensured ease in understanding the insight and ideas regarding the research problem under investigations.

The study used quantitative and qualitative research designs. The information gathered was used to analyze the challenges affecting women career mobility in public universities in comparison to private universities in Kenya.

Descriptive Survey design is also best suited to gather information on current practices. In this study, Survey design was selected because it entails examining the current status of the factors that affect women career mobility in university management. Questionnaires, interviews and document analysis guide were the major instruments for collecting data. The sampling design comprised a combination of stratified random sampling, simple random sampling and purposive sampling techniques.

\section{Findings of the study}

The findings of the study were analyzed and discussed under the following thematic areas.

\section{Women Career Mobility in Kenya}

In Kenya the situation is not any different from other countries in the world. Traditionally, women were viewed as inferior to men and marginalized in all sectors of development, Chacha (2004). A study by Suda (1991) on social cultural and demographic factors in female labour force participation in Kenya revealed that although Kenyan women have joined the labour force in large and increasing numbers over the last two decades due to increased access to education, majority of them are still concentrated in traditional "female occupations" and the informal sector. The urban labour force participation rate for women in Kenya had increased from 30\% in the early eighties to 56\% in 1995. Despite their growing participation in the workforce, there are still very few women in the top echelons of public decision and policy making positions in Kenya.

The Commission for Higher Education (CHE) report of 2011/ 2012 revealed than women occupied lower managerial positions as deans of students, welfare officers and students counsellors, CHE (2011). The situation was more or less the same in public and private universities in Kenya. However, this study observed that more women held management position in public universities that in private universities in Kenya. In one of the private universities in Kenya, out of the seven deans of faculties only one was a woman.

In another private university, out of the eleven members of the University Council in the 2011/2012 academic years only two were women. The university had over 6 women qualified with PhDs and over 5 years' experience in university management. The ten member university council had only two women and out of the seven heads of faculties (deans) only one was a woman. In this particular university all the five directors were men including the four campus directors and the ICT director, CHE (2011). In yet another university on the other hand, out of the sixteen (16) senior management positions only two (2) were held by women, this is $12.5 \%$ CHE (2011). In a second public university out of the sixty one (61) heads of departments only seventeen (17) are women, this is $27.8 \%$. This clearly shows that women career mobility is far below that of their male counter parts. In this university, over 15 women were qualified academically with $\mathrm{PhDs}$ and the required years of university management which meant that they were qualified for promotion. Academic qualification was therefore not an hindrance to women career mobility. This study was necessary to find out what affects women career mobility in public and private universities in Kenya.

\section{Establishment of Men and Women in Management Positions in Public universities in comparison to private universities in Kenya}

Governance and management of education are equally male-dominated. Most heads of institutions especially of higher learning institutions are males. In the seven public universities, there were only two female chancellors recruited recently by Kenyatta University and Jomo Kenyatta University of science and technology respectively.

Low representation of women at the university level implied that their ideas, input in policy and decision-making was minimal and therefore their interests were not taken care of as most decisions were made from the men's point of view. This impacted negatively on the prospects of women career mobility in university management. 
The study also sought to establish the number of men and women holding management positions in public universities in comparison to private universities in Kenya. Management positions included the chairmen of departments, directors of campuses/ programmes, deans of Faculties/Schools, Registrars, DVCs and VCs. The study observed that most management positions in public and private universities in Kenya were held by men. The findings are shown on Tables 1.1 and 1.2 respectively.

Table 1.1: Staff establishment in management positions in selected public universities in Kenya in 2010 $n=468$

\begin{tabular}{|c|c|c|c|c|c|c|c|c|c|c|c|c|c|c|c|c|c|c|}
\hline \multirow{3}{*}{$\begin{array}{l}\text { Management } \\
\text { Position } \\
\text { University }\end{array}$} & \multicolumn{18}{|c|}{ Public Universities } \\
\hline & $\begin{array}{l}\text { Un } \\
\mathrm{Me}\end{array}$ & versit & $\begin{array}{l}\mathrm{C} \\
\mathrm{W} \\
\mathrm{n}\end{array}$ & me & $\mathrm{Ur}_{\mathrm{r}}$ & iver & $\begin{array}{l}\text { ity } \\
\text { W } \\
n\end{array}$ & me & $\mathrm{U}_{\mathrm{l}}$ & ivers & $\begin{array}{l}\mathrm{y} \mathrm{L} \\
\mathrm{W} \\
\mathrm{n}\end{array}$ & me & & ivers & $\begin{array}{l}\mathrm{ty} \\
\mathrm{W} \\
\mathrm{n}\end{array}$ & me & Tot & \\
\hline & $\mathrm{f}$ & $\%$ & f & $\%$ & $\mathrm{f}$ & $\%$ & $\mathrm{f}$ & $\%$ & $\mathrm{~F}$ & $\%$ & $\mathrm{f}$ & $\%$ & f & $\%$ & $\mathrm{f}$ & $\%$ & $\mathrm{f}$ & $\%$ \\
\hline VC's & 1 & 0.2 & 0 & $\begin{array}{l}0 . \\
0 \\
0 .\end{array}$ & 0 & $\begin{array}{l}0 . \\
0 \\
0 .\end{array}$ & 1 & $\begin{array}{l}0 . \\
2 \\
0 .\end{array}$ & 1 & 0.2 & 0 & $\begin{array}{l}0 . \\
0 \\
0 .\end{array}$ & 0 & 0.0 & 1 & $\begin{array}{l}0 . \\
2 \\
0\end{array}$ & 4 & 0.9 \\
\hline DVC's & 4 & 0.9 & 1 & $\begin{array}{l}2 \\
0 .\end{array}$ & 2 & $\begin{array}{l}4 \\
0 .\end{array}$ & 1 & $\begin{array}{l}2 \\
0 .\end{array}$ & 2 & 0.4 & 1 & $\begin{array}{l}2 \\
0 .\end{array}$ & 4 & 0.9 & 0 & $\begin{array}{l}0 \\
0 .\end{array}$ & 15 & 3.2 \\
\hline Registrars & 5 & $\begin{array}{l}1.1 \\
10 .\end{array}$ & $\begin{array}{l}1 \\
1\end{array}$ & $\begin{array}{l}2 \\
2 .\end{array}$ & 3 & $\begin{array}{l}6 \\
1 .\end{array}$ & 0 & $\begin{array}{l}0 \\
0 .\end{array}$ & 2 & 0.4 & 1 & $\begin{array}{l}2 \\
0 .\end{array}$ & $\begin{array}{l}3 \\
1\end{array}$ & 0.6 & 0 & $\begin{array}{l}0 \\
0 .\end{array}$ & 15 & 3.2 \\
\hline Deans & 49 & 5 & 1 & $\begin{array}{l}4 \\
1 .\end{array}$ & 6 & $\begin{array}{l}3 \\
1 .\end{array}$ & 4 & $\begin{array}{l}9 \\
0 .\end{array}$ & 6 & 1.3 & 2 & $\begin{array}{l}4 \\
0 .\end{array}$ & $\begin{array}{l}1 \\
1\end{array}$ & 2.4 & 4 & $\begin{array}{l}9 \\
1 .\end{array}$ & 93 & 19.9 \\
\hline Directors & $\begin{array}{l}15 \\
11\end{array}$ & $\begin{array}{l}3.2 \\
25 .\end{array}$ & $\begin{array}{l}6 \\
2\end{array}$ & $\begin{array}{l}3 \\
5 .\end{array}$ & $\begin{array}{l}5 \\
2\end{array}$ & $\begin{array}{l}1 \\
5 .\end{array}$ & $\begin{array}{l}2 \\
1\end{array}$ & $\begin{array}{l}4 \\
2 .\end{array}$ & $\begin{array}{l}1 \\
3\end{array}$ & 0.2 & 1 & $\begin{array}{l}2 \\
1 .\end{array}$ & $\begin{array}{l}4 \\
4\end{array}$ & 3.0 & $\begin{array}{l}7 \\
2\end{array}$ & $\begin{array}{l}5 \\
4 .\end{array}$ & $\begin{array}{l}51 \\
29\end{array}$ & 10.9 \\
\hline HODs & 8 & 2 & 7 & 8 & 7 & 8 & 1 & 4 & 5 & 7.5 & 7 & 5 & 5 & 9.6 & 0 & 3 & 0 & 62.0 \\
\hline Total & $\begin{array}{l}19 \\
2\end{array}$ & $\begin{array}{l}41 . \\
0\end{array}$ & $\begin{array}{l}4 \\
6\end{array}$ & $\begin{array}{l}9 . \\
8\end{array}$ & $\begin{array}{l}4 \\
3\end{array}$ & $\begin{array}{l}9 . \\
2\end{array}$ & $\begin{array}{l}1 \\
9\end{array}$ & $\begin{array}{l}4 . \\
1\end{array}$ & $\begin{array}{l}4 \\
7\end{array}$ & $\begin{array}{l}10 . \\
0\end{array}$ & $\begin{array}{l}1 \\
2\end{array}$ & $\begin{array}{l}2 . \\
6\end{array}$ & $\begin{array}{l}7 \\
7\end{array}$ & $\begin{array}{l}16 . \\
5\end{array}$ & $\begin{array}{l}3 \\
2\end{array}$ & $\begin{array}{l}6 . \\
8\end{array}$ & $\begin{array}{l}46 \\
8\end{array}$ & $\begin{array}{l}100 . \\
0\end{array}$ \\
\hline
\end{tabular}

Source: Commission for University Education

With reference to the public universities as seen on Table 1.1, the study established that in one public university headed by a male VC, out of the five DVCs, only one was a woman. In the same university, out of the 60 deans of Faculties, 49 $(82 \%)$ were men and only $11(18 \%)$ were women. Out of 145 Heads of Departments, there were $118(81 \%)$ men and 27 (19\%) women.

The information on Table 1.1 revealed gender disparity in the management of public universities in Kenya. The study showed that in the four public universities selected for this study, apart from the two VCs, all the other senior management positions were dominated by men.

The study found out that more men than women held management positions in both public and private universities in Kenya. A comparison of women in management positions in public and private universities in Kenya revealed that there were few women in management positions in the two categories of universities as shown on Tables 1.1 and 1.2.

The study findings on the establishment of management positions in private universities in Kenya are presented on Table 1.1

Table 1.2: Establishment of staff in management positions in selected private universities in Kenya by 2010 $(\mathbf{n}=95)$

\begin{tabular}{|c|c|c|c|c|c|c|c|c|c|c|c|c|c|c|}
\hline \multirow{4}{*}{$\begin{array}{l}\text { Management } \\
\text { Position }\end{array}$} & \multicolumn{14}{|c|}{ Private Universities } \\
\hline & \multirow{2}{*}{\multicolumn{4}{|c|}{$\begin{array}{l}\text { Men Women } \\
\text { University } 2\end{array}$}} & Men & & Nome & & Mer & & Wom & & \multicolumn{2}{|c|}{ Total } \\
\hline & & & & & \multicolumn{4}{|c|}{ University 1} & \multicolumn{4}{|c|}{ University 3} & & \\
\hline & $f$ & $\%$ & $\mathrm{f}$ & $\%$ & $f$ & $\%$ & $f$ & $\%$ & $f$ & $\%$ & $f$ & $\%$ & $f$ & $\%$ \\
\hline $\mathrm{VCs}$ & 1 & 1.1 & 0 & 0.0 & 1 & 1.1 & 0 & 0.0 & 0 & 0.0 & 1 & 1.1 & 3 & 3.2 \\
\hline $\mathrm{DVC}_{s}$ & 2 & 2.1 & 0 & 0.0 & 3 & 3.2 & 0 & 0.0 & 2 & 2.1 & 0 & 0.0 & 7 & 7.3 \\
\hline Registrars & 2 & 2.1 & 0 & 0.0 & 3 & 3.2 & 0 & 0.0 & 2 & 2.1 & 0 & 0.0 & 7 & 7.3 \\
\hline Deans & 5 & 5.3 & 1 & 1.1 & 4 & 4.2 & 2 & 2.1 & 3 & 3.2 & 0 & 0.0 & 15 & 15.9 \\
\hline Directors & 6 & 6.3 & 4 & 4.2 & 3 & 3.2 & 1 & 1.1 & 2 & 2.1 & 2 & 2.1 & 18 & 18.9 \\
\hline HODs & 20 & 21.1 & 5 & 5.3 & 10 & 10.5 & 5 & 5.3 & 3 & 3.2 & 2 & 2.1 & 45 & 47.4 \\
\hline Total & 36 & 37.9 & 10 & 10.5 & 24 & 25.3 & 8 & 8.4 & 12 & 12.6 & 5 & 5.3 & 95 & 100.0 \\
\hline
\end{tabular}

Table 1.2 shows that all the seven DVCs and registrars in the private universities were men. These gender disparities cut across the public and private universities as seen in the management positions as shown on Table 4.11. For instance, in public universities out of the 51 directors, majority $35(68.6 \%)$ were male and $16(31.4 \%)$ were female. In the private universities on the other hand, out of the 18 directors, $11(61 \%)$ were male and $7(39 \%)$ were female. This in comparison to public universities shows that gender disparity existed in both categories of the university as shown on Table For instance among the 93 deans of Faculties in the public universities, majority 72 (77.4\%) were male compared to 21 (22.7\%) female whereas at the private universities out of the 15 deans, 12. This scenario was not different among the heads of departments. Among the 290 heads of departments in the four public universities, majority 225 (77.6\%) were males and 
the rest $65(22.4 \%)$ were female. In the private universities on the other hand, out of the 45 HODs, 33 (73.3\%) were males and only $12(26.7 \%)$ were females.

The study observed that women did not progress at the same rate in their careers with their male counterparts in public and private universities in Kenya. This implies that women play minimal role in the management of private universities in Kenya and therefore all the decisions made are made from the men's point of view leaving little room to discuss ways of enhancing women career mobility. This impacted negatively on women career mobility in public and private universities in Kenya. It could also have implied that the women in management in the public and private universities could not compete on the same footing with their male counterparts. This disparity is an indication that the interventions put in place by the public and private universities to enhance women career mobility were yet to bear fruits. The study concurs with one by National Council for Science and Technology (NCST, 2010) which observed that the university management in Kenya was male dominated and female representation was minimal.

The study by NCST (2010) further observed that there were no deliberate attempts by public universities to ensure that females are elevated to management in public universities in Kenya The low number of women in management position in universities could be attributed to lack of implementation of policies on recruitment and promotion by the public and private universities in Kenya. This is likely to create uneven playing field for men and women in management. For gender equity to be achieved both men and women must have equal opportunities and this can only be achieved through implementation of relevant policies that enhance gender equity at all levels of management.

This study concurs with the liberal gender theories that there is need to increase women's power and influence in university management by working within the current policies and structures. Reforming and changing the practices within the existing structures and policies of the university would eventually result in a greater equity in gender representation at the university management in both public and private universities in Kenya.

Challenges hindering women career mobility in public universities in comparison to private universities in Kenya This study revealed that men occupy more management positions in university management in Kenya. This study therefore, sought to establish the challenges that hindered women career mobility in public universities in comparison to those in private universities in Kenya.

Interviews were conducted among women deans, directors, deputy VCs and VCs on the challenges affecting women career mobility in university management.

\section{Lack of organizational and career mentors}

Mentors are considered critical for career advancement of protégés through sponsorship, coaching, role modelling, and counselling. A key impediment to women advancement is the lack of organizational and career mentors. At least five in every ten women interviewed highlighted various problems associated with the issue of mentoring such as the fact that there were fewer women mentors, 'overbearing' male bosses, sometimes 'flirtatious' male mentors who tend to see women as sex objects. The realities in universities in Kenya align with Scandura (1999) who suggest that there is scarcity of female mentors at higher organizational ranks, and because crossgender mentoring relationship was less likely to engage in close friendship and that social roles that involve after work networking activities could be threatened with an appearance of romantic involvement.

\section{Organizational networks and interpersonal relationships}

Four in every ten women interviewed from public universities compared to five in every ten women respondents in private universities cited lack of networks essential for career advancement. Many women expressed the need to more opportunities for women faculty to come together to network and collaborate. One woman dean of faculty had this to say: Successful organizational networking positively impacts career outcomes, including access to information, social and professional advice, and increased job opportunities, promotions and career satisfaction. Women are lacking in networks that are important for advancement. Women are isolated in their individual needs. Networking opportunities at the universities are lacking.

One female DVC from a public university noted that cultural values restrain female managers from entertaining their colleagues in private clubs or on the golf course, places very well known among Kenyans as congenial for establishing networks and learning through the grapevine. Because of such exclusion, female managers have limited opportunity to socialize with influential executives (usually males) who could help promote their career mobility. One of the respondents pointed out that:

Networking among women folks will be one of the best thing that can happen to women career development as there will be so much to share as long as we keep focus. I do recognize that it will come as a challenge as class and status might be created in the course of it thereby making it impossible for some to be part of it. Because fear spring from ignorance, once you create a fence for some, the network will be labelled negatively. I am convinced that as women we stand to gain so much if we network in a coordinated manner.

The findings of this study showed that female managers strongly felt that lack of access to professional networks negatively impacted on their career mobility. The women respondents felt the need to consider initiating and organizing a women executive club to provide a forum for the interchange of ideas and experiences among the female managers. The organization can provide support, networking and training members and also serve as a lobbying group on behalf of female managers' interests in university management. 


\section{Cultural Stereotypes}

Other factors that affected women career mobility in universities were cultural discrimination which considers women inferior to men. Other women managers also indicated age as a barrier to their career development. Three respondents from private universities indicated that young women were denied promotion on the basis that they would take maternity leave and also be hindered by family obligations.

Four in every ten respondents in public universities compared to three in every ten in private universities noted that some challenges faced by women in career mobility were tied to different societal roles played by men and women. There are those jobs that are traditionally known to be men's and vice versa, therefore those women who venture into jobs labelled to be men's are likely to face serious challenges. This study agrees with Flanders (1994), he observed that women suffer from age discrimination more than men. Women are more generally perceived to be less ambitious and to have reached their peak at earlier age than men. In addition, older women are also perceived to be less qualified than men because of maternity breaks and as having more time consuming family commitments. Flanders (1994, p.109), however , points out that in reality a woman's family commitment are likely to decline with age, as her children become older and more independent. He also observed that employers often believe that women are less committed to work and less able to undertake a full time career than men, due to their biological make up, rather than ability. However a study by Families and Work Institute of Boston College, 2002) observed that young women are equally ambitious as their male counterparts to develop successful managerial careers. This view is supported by catalyst (2004) who noted that equal number of men $(57 \%)$ and women ( $55 \%$ ) want to occupy the most senior role (CEO or equivalent) in an organisation; emphasising that ambition for the most senior organizational position is not lacking in women.

One out of every ten women managers interviewed pointed at male dominance in leadership and cultural discrimination, which considers women inferior to men as one of the challenges. Majority of men and women interviewed felt that most universities preferred to appoint men to senior positions of management. These often-discouraged women and they opted to sit back as their male colleagues applied for promotions. Women are also seen as unlikely to have male characteristics which are dominant and aggressive and are considered as suited to leadership positions.

\section{Societal expectations of men and women}

Three in every ten respondents from public universities compared to three in private universities observed that some challenges faced by women in career mobility were tied to different societal roles played by men and women. They felt that men were given more challenging projects, which are also well paying while their female counterparts are given more soft roles like student deanship and counselling. Women are often underrated in their performance. They observed that this is a perception that females could not deliver like their counterparts. This has seen women being denied jobs that they have the experience, expertise, and qualifications. These jobs are offered to the males. They observed that, when a woman and man walk into the interview room, after a successive interview qualification, the man has a high probability of being granted the job by the company in favor of the women. This is a customary manifestation that should fade away from the today's university executives and managers.

One of the female university managers who shared her experience as she climbed the career ladder had this to say:

After successfully going through the interview my immediate supervisor refused me to be deployed in his department. The only reason he had was that he feared I could not manage the department because women had a myriad of issues to sort. It took a lot of convincing from me and other senior managers for him to allow me work in his department. I had to work extra hard to prove myself. I went through a hard time. As if what I was going through at work was not enough, at home my husband was on my case, I had to get home early and any time I had to be late at work I had to call in advance or else I would be in trouble. All because everyone believed the place for a woman is in the kitchen.

These findings concur with those of League of Kenya Women Voters, (2005), pointed out that through socialization, girls and women learn and internalize subservient beliefs, values and attitudes against themselves. Men have negative perceptions of girls and women's abilities. Although participation in education by the marginalized groups is generally low, girls and women are more marginalized, especially because of their gender roles, and inadequate access to and control of resources. Among some societies, female education is not a priority.

The respondents were further asked to give their opinion on the challenges that they perceived to have affected women career mobility in public universities in comparison to private universities. The respondents pointed out at a number of factors that acted as impediments to women career mobility in public and private universities in Kenya. Tables 1.3 and 1.4 illustrates the findings of Journal of Advance Research in Social Science and Humanities ISSN: 2208-2387. 
Table 1.3: Challenges hindering women mobility career in public universities in Kenya

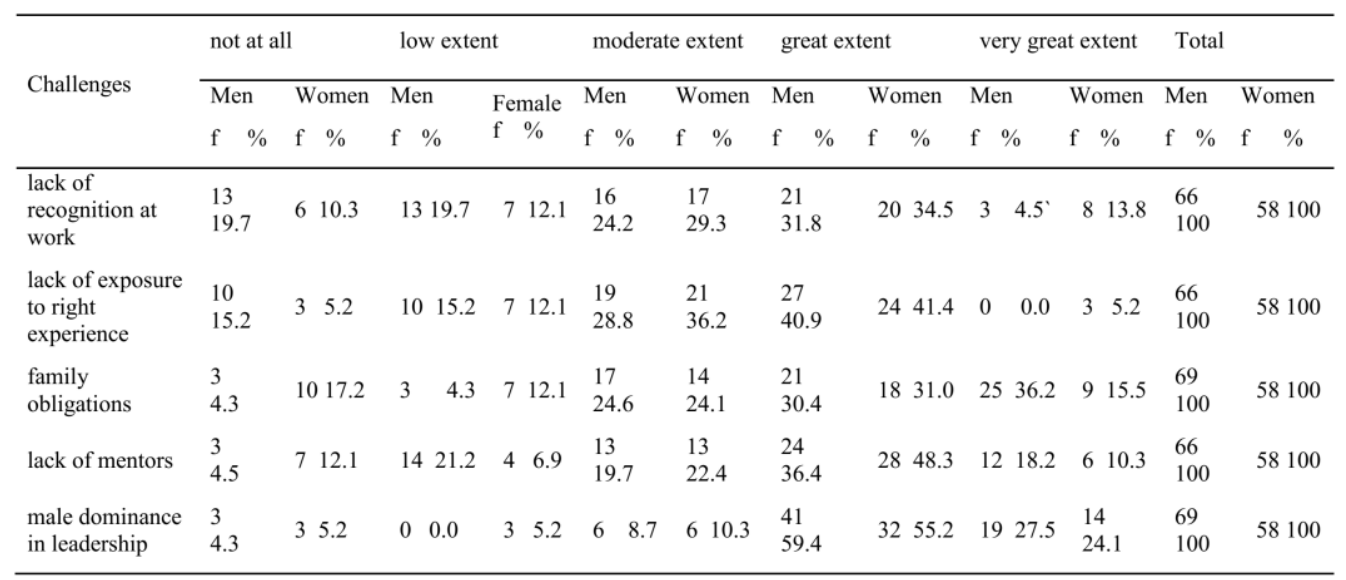

In public universities, $41(59.4 \%)$ male and $32(55.2 \%)$ female respondents said that male dominance in leadership was a great challenge. This observation was supported by those in private universities among $11(40.7 \%)$ male and $16(38.1 \%)$ female. Among women in public universities, 28 (48.3\%) indicated that lack of mentors was a hindrance to women career mobility in comparison to $9(22.0 \%)$ of those in private universities. Family obligations were seen as slightly hindering women career mobility at $25(36.2 \%)$ among women in public universities and $18(31.0 \%)$ among men compared to 12 $(44.4 \%)$ male and $8(19.5 \%)$ female in private

universities.

This agreed with the studies by feminist/gender theories and related explanations made by Anker (1997) who attributed subordinate positions being held by women to the fact that women carried out all the tough duties at the home front, and had little time at their disposal to work outside the home. This also agrees with other studies which indicated that mentoring and networking relationships are also potentially valuable for women's advancement in view of boosting emotional support and confidence and careers satisfaction, Resign et a; (1998). A study carried out by Cross (2010) revealed a clear realization among the female managers that their male counterparts were overtly engaging in networking activities which gave them increased levels of visibility among the senior management team. However, women in male dominated organizations often have limited networking and mentoring opportunities. This is so for women in university management in Kenya because they are male dominated.

The findings from private universities are shown on Table 1.4

Table 1.4 Challenges hindering women career mobility in private universities in Kenya

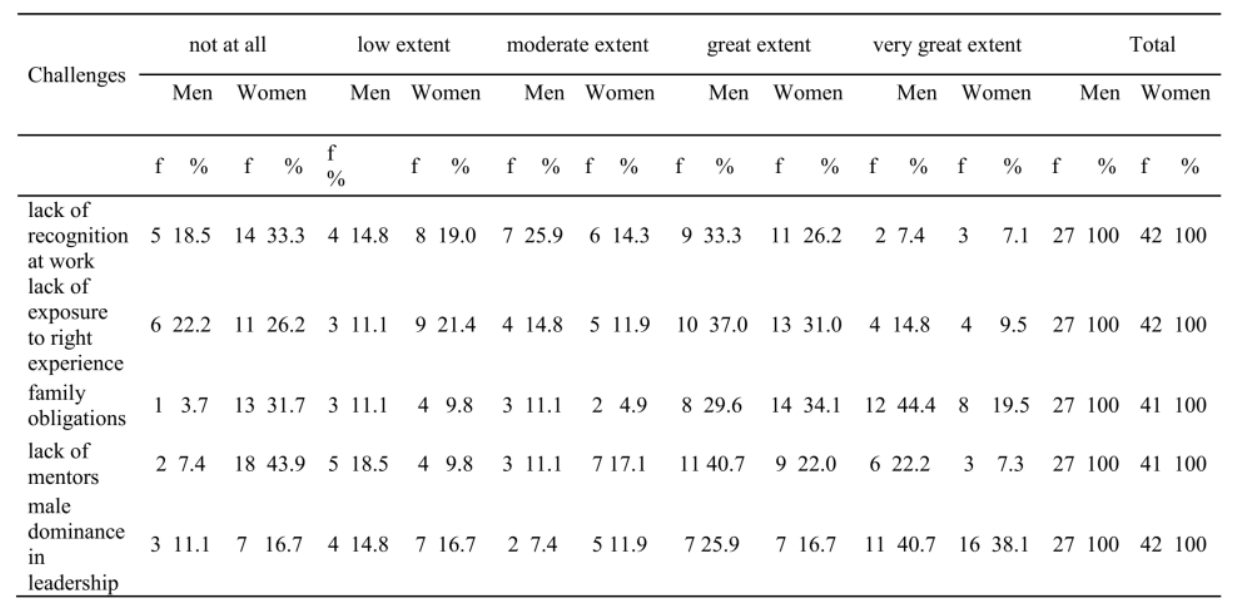

The respondents in private universities on the other hand indicated that the factors which hindered career mobility were; family obligations $12(44.4 \%)$ male and $8(19.5 \%)$ female and lack of mentors $11(40.7 \%)$ among male and $9(22.0 \%)$ in female respondents. Other respondents indicated that male dominance was a challenge as seen among $11(40.7 \%)$ male and $16(38.1 \%)$ female respondents in private university category. This calls for an overhaul in the process of promotion and recruitment in public and private universities in Kenya. This agrees with the findings by Auster (1993) who observed that women absence in the ranks of university management are a telling signal that the whole process of selection, recruitment and promotion in universities is in need of a major overhaul.

\section{Conclusions and Study:}

Based on the findings of the study following conclusions were made: -

i. Men occupied more management positions compared to women in both public and private universities. 
ii. The study conducted that there were more women in management positions in public universities in comparison to private universities in Kenya.

iii. The study concluded that women faced insurmountable barriers as they navigated through their career ladder in public and private universities in Kenya. These included; lack of policy implementation, lack of mentors, lack of networks and cultural stereotypes.

iv. The study concluded that women can overcome the challenges facing them in their career mobility in public and private universities in Kenya through realizing that gender inequalities exist and consciously working towards overcoming these inequalities that hinder their career mobility.

\section{Recommendations of the study}

Based on the findings of the study and the study objectives, the research makes the following recommendations:

i. Men and women should be given equal opportunity during recruitment and promotion in public and private universities in Kenya by ensuring implementation of policies on recruitment and promotion to enhance women career mobility in educational management.

ii. Women should be conscious of the gender inequalities and consciously make efforts to overcome the challenges hindering their career mobility in public and private universities in Kenya.

\section{References}

[1].Anker, R. (1997). "Theories of Occupational Segregation by Sex: an overview", International Labour Review, Vol.136 No.3,pp.315-39.

[2].Catalyst (2004).Census of women corporate officers and top earners in CanadAvailable at:www.catalystwomen.org/knowledge/titles.

[3].Chacha .N.C. (2004). Reforming Higher Education in Kenya, Challenges, Lessons and Opportunities, a paper represented at the State University of New York Workshop, Kenya, Naivasha. Unpublished conference paper. CHE ; (2011). Kenyan Higher Education (www.che.co.ke)

[4].Cross C (2010) Barriers to the executive suite evidence from Ireland. Leadership \& Organization Development Journal 31(2):104-119.

[5].Cubillo, L.\& Brown, M. (2003). Women into educational leadership and management: International differences?"Journal of Educational Administration, Vol. 41 No. 3, 278-91.

[6].Dines, E. (1993).Women in Higher Education Management. Paris: UNESCO / Commonwealth Secretariat.

[7].Flanders ML (1994) Breakthrough: The Carrier Women's Guide to Shuttering The Glass Ceiling, Paul Chapman Publishing, London.pp.1-11.

[8].Government of Kenya(2005). Constitution of Kenya Review Commission; Inheritance of Land and other pieces of property in the family. Nairobi: (GoK, World Bank, (2005). Gender Stats. (online) Available from: http://debvdata. worldbank.org/

[9].Genderstats. 1997)League of Kenya Women Voters, (2005).CEDAW and Beijing, Platform for Action made simple. Kenya:Nairobi. League of Kenya Women Voters.

[10]. Mills, S. (1998): "Postcolonial Feminist Theory" in S. Jackson and J. Jones eds., Contemporary Feminist Theories(Edinburgh: Edinburgh University Press)

[11]. pp.98-112World Bank, (2005). Gender Stats.(online) Available from: http://debvdata. worldbank.org/ Genderstats.Journal of 